\title{
Assessing the contribution of subsistence economy in income generation of rural households in Yakutia
}

\author{
Tuyara Gavrilyeva ${ }^{1,2 *}$, Anna Naberezhnaya ${ }^{3}$, and Marina Ivanova ${ }^{4}$ \\ ${ }^{1}$ Institute of Engineering \& Technology, North-Eastern Federal University, 50 Kulakovsky str., 677000, \\ Yakutsk, Russia \\ ${ }^{2}$ DRESS, Federal Research Centre "YSC", SB, RAS, 2 Petrovsky str., 677000, Yakutsk, Russia \\ ${ }^{3}$ Financial \& Economic Institute, North-Eastern Federal University, 58 Belinsky str., 677000, Yakutsk, \\ Russia \\ ${ }^{4}$ Institute of Modern Languages \& International Studies, North-Eastern Federal University, 58 Belinsky \\ str., 677000, Yakutsk, Russia
}

\begin{abstract}
Traditional economic activity is a significant part of nonobserved economy sustaining in regions with a large share of rural population. Non-transparency of subsistence economy hampers assessment of its contribution to goods and services production, the number and income levels of self-employed. The paper summarizes a study of contribution of private subsidiary plots and other forms of traditional economic activity (hunting, fishery, gathering) in rural household incomes and selfemployment in Yakutia based on a representative sociological survey of 2017-2019. The share of in-kind income in household budgets estimated by the authors averages $15.7 \%$, partly compensating for cash income deficit and helping alleviate poverty problem in the region.
\end{abstract}

\section{Introduction}

The problem of poverty and its depth across various social groups is one of the relevant methodological problems in Russia. A number of studies indicate that rural population engaged in traditional economic activity is poorer than urban population [1]. At the same time, subsistence and semi-subsistence farms are essential to modern global agricultural policy, making a significant contribution to production of food, supporting rural economy, and conservation of biodiversity. A significant part of rural population earns livelihoods thanks to this sector. Semi-subsistence private farms and private subsidiary plots are subject to demographic, commercial, and technological changes. They face problems associated with poor marketability of products and low labor efficiency, as well as ensuing poverty and a shrinking rural population [2].

Subsistence economy is not transparent for the state, which makes it difficult to evaluate its contribution to agricultural production and national economy as a whole. Unobservable economy of the households is largely confined to subsistence production and redistribution,

* Corresponding author: tuyara@list.ru 
including informal work at private land plots, informal credit relationships, and inter-family mutual aid. People employed in the informal household economy do not consciously conceal their activity from the state; the state just overlooks them [3]. Therefore, agricultural censuses and other forms of surveying private subsidiary plots and private farms are so important [4].

Sustainability of traditional economic activity is one of the distinctive features of the Sakha Republic (Yakutia). Due to private farming, traditional types of economic activity, including reindeer, cattle, and horse breeding, are still rooted in Yakutia. The proportion of rural population as of early 2020 makes $34.4 \%$, which is significantly higher than Russia's average $(25.4 \%)$. This is one of the factors of a high poverty rate; in 2018 the share of Yakutia's population with incomes below the subsistence minimum reached $19.0 \%$, against nationwide rate of $12.6 \%$ [5]. The share of Yakutia's population employed in the informal sector is also higher than in Russia as a whole. In 2018, it was estimated at 80.0 thousand people, which is $8.3 \%$ of the population or $23.2 \%$ of the total number of people employed in the economy. The unemployment rate is the highest in the Far Eastern Federal District [6]. Lack of reliable information regarding the depth of poverty in the rural population, as well as regarding their income from traditional economic activity, handicaps effective social policy.

The purpose of this study is to assess the contribution of in-kind income from private subsidiary plots and other kinds of traditional economic activities (hunting, fishery, and gathering) in generating budgets of rural households in Yakutia.

\section{Materials and Methods}

The study database is the results of a sociological survey undertaken by the team of the RFBR research project No. 17-02-00619-OGN in the Sakha Republic (Yakutia) in 20172019. The object of the general population was private households in rural settlements of the republic. The republic consists of 36 municipalities: 34 municipal districts and 2 urban districts. The survey embraced 10 districts, grouped under five socio-economic zones of the republic (Eastern, Western, Southern, Northern (Arctic), and Central). The study was based on a sample survey of 383 private households in rural settlements of Aldansky, Amginsky, Vilyuisky, Gorny, Megino-Kangalassky, Mirninsky, Namsky, Nyurbinsky, SredneKolymsky, and Ust-Maysky districts of the SR (Y) with a confidence level of 95\%, error 5\%. The total number of the surveyed population made 1,454 people. Stage sampling based on the territorial principle was implemented to form a sampling frame. The first stage is formed by quota sampling in 5 republic-wide socio-economic macro-districts based on the 2010 AllRussian Population Census. Next stage: random sampling of rural settlements to form a select list of households, where accessibility is crucial for 'coverage' of settlements, i.e. possibility to travel to a settlement. Questionnaire data entry and analysis was performed in SPSS Statistics 22.0 software application. Information from the Federal State Statistics Service (hereinafter - Rosstat) and its territorial administration in the Sakha Republic (Yakutia) (hereinafter - Sakha(stat)) was also used.

The questionnaire consisted of 120 questions, structured into several blocks: gender and demographic factors, job availability, profession and education, cash income and social transfers, effectiveness of social support measures, consumption, accessibility of natural environment, social, road, and communal infrastructure, mobile communication and Internet penetration rate, engagement in traditional economic activities, and other questions.

\section{Results and Discussion}

According to the policy of the UN Food and Agriculture Organization, family and private farms are a facility of organizing agricultural production, including forestry, fisheries, 
livestock sector, and aquaculture. They are essential for sustainable development of rural communities and access to healthy food. Their contribution to local food supply, food security, and food sovereignty is widely recognized at a global scale. In Europe, they are often seen as an alternative to large and specialized farms [7]. Family farm-based agriculture can be an effective solution to economic, social, and global environmental problems, among other, due to the fact that rapidly growing world population is putting an increasing pressure on resources, which paves the way for a global food crisis $[2,8]$.

Private subsidiary plots (hereinafter - PSPs) in the North are a form of engagement in agricultural production, traditional activities and industries, subject to which agricultural and commercial products are produced by personal labor of a citizen and their family members for own consumption, as well as for sale in order to satisfy their material or other needs. Citizens exercise their right to run a PSP through obtaining or acquiring a land plot in the manner prescribed by law [9]. Labor at a private subsidiary plot, embracing mainly traditional economies (hunting and fishing, cattle breeding, horse breeding, reindeer herding), in the harsh climatic conditions of the North is the most common form of self-employment of the republic's rural population. The need for self-employment in rural communities is dictated by the tightness of workplaces in rural areas, wage gap between different sectors of economy, and objective economic hardships of many rural families [1].

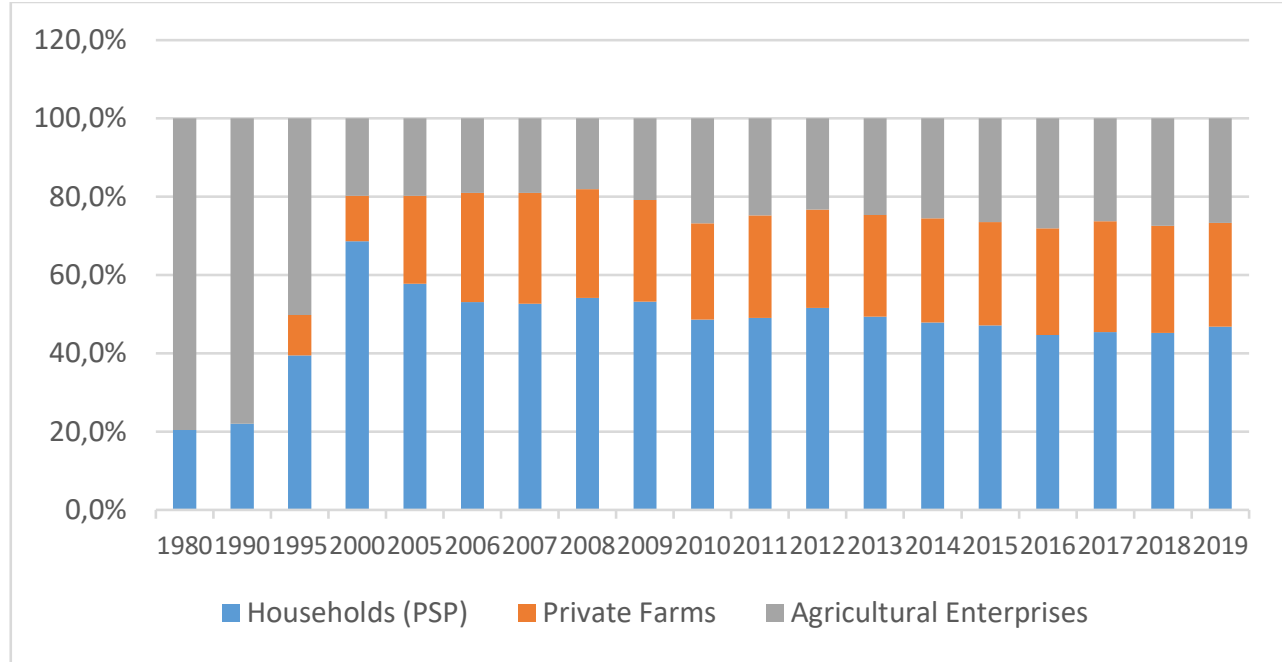

Fig. 1. Agricultural Production by Type of Unit, \%

According to the 2016 All-Russian Agricultural Census, the number of private subsidiary farms in Yakutia was 97,631. It means that $83 \%$ of rural households and $6 \%$ of urban households were involved in food self-sufficiency. The average land area per one PSP in Yakutia was 2.2 hectares; 2.5 hectares in rural areas and 0.1 hectares in urban areas [10]. Experts note that access to land and markets is one of the main constraints hindering the development of PSPs. Support from regional and local authorities is essential for product sales and making land available for PSPs. Growth of livestock number and their increased productivity is in direct correlation with the fodder base [9].

PSPs currently account for $46.8 \%$ of agricultural production in Yakutia (Fig. 1), including $42.3 \%$ of livestock farming and $57.3 \%$ of crop farming. In 2019 , the rate of production was estimated at RUR 12,204.8 million, or USD 188.875 million (average annual exchange rate of dollar to ruble is 64.618). Average annual proceeds amount to about RUR 120,005 (USD 1,934.6) per household. Farmers sell the surplus of their product, which is the only 
opportunity to earn ready money. In conditions of significant prevalence of poverty, it is extremely important. The marketability of PSPs or the share of sold products in the total production is $65 \%$ of milk, and $54.3 \%$ of meat.

The most significant measures of state support for PSPs in Yakutia include:

1. A package of individual legislative acts of the Sakha Republic (Yakutia). As per the Law of the Sakha Republic (Yakutia) dated June 14, 2000 No. 207-II 'On private subsidiary plots of citizens in the Sakha Republic (Yakutia)', a farm's area is limited to 2.5 hectares, including a vegetable garden, a greenhouse, berry bushes, a stable, and a barn. For traditional types of animal husbandry (reindeer herding, horse breeding), additional incentives have been put in place in Yakutia, including allotment of larger land plots and acreage.

2. Subsidies for traditional economic activities. The main mechanism operating in Yakutia is purchasing milk from the population along with other agricultural producers, which provides ready money. In 2002, the amount of the subsidy was RUR 11.2 per $1 \mathrm{~kg}$ of raw milk, in 2014 - RUR 19.2, in 2015-2016 - RUR 30. From January 1, 2017, as per the Law of the Sakha Republic (Yakutia) dated April 26, 2016 1619-3 No. 791-V 'On development of agriculture in the Sakha Republic (Yakutia)', milk procurement system was updated.

Since then financial support is transferred to municipal districts in form of subvention funds to cover production and processing of livestock products and procurement of raw milk. The procurement price was set at RUR 45 per $1 \mathrm{~kg}$ [11]. In 2019, Lensky District increased the purchase price to RUR 70 per $\mathrm{kg}$ at its own expense, which is an absolute record for Yakutia. Other projects in the field of social entrepreneurship are being discussed in the republic, including procurement of berries, mushrooms, etc. from the population. This process involves municipal districts that have a well-developed transport network, which enables access to sales and distribution of local products.

3. Unlike other regions of Russia, Yakutia does not take incomes from PSPs into account for fiscal purposes. For this end, the standards of net income from sales of fruitage and products obtained in a private subsidiary plot, which are established as per the requirements of the Federal Law dated April 05, 2003 No. 44-Ф3 'On procedure of accounting for income and calculation of average per capita income of a family and income of a citizen living alone for recognizing them as poor and providing them state social support', were deemed equal to 0 (Resolution of the SR (Y) Government dated March 26, 2009 No. 129, as amended by the resolution of the SR (Y) Government dated June 30, 2015 No. 214). In a number of other regions with a similarly high share of rural population and poverty rate, such standards have been established, which allows the governing bodies to somewhat underestimate the number of poor citizens. 


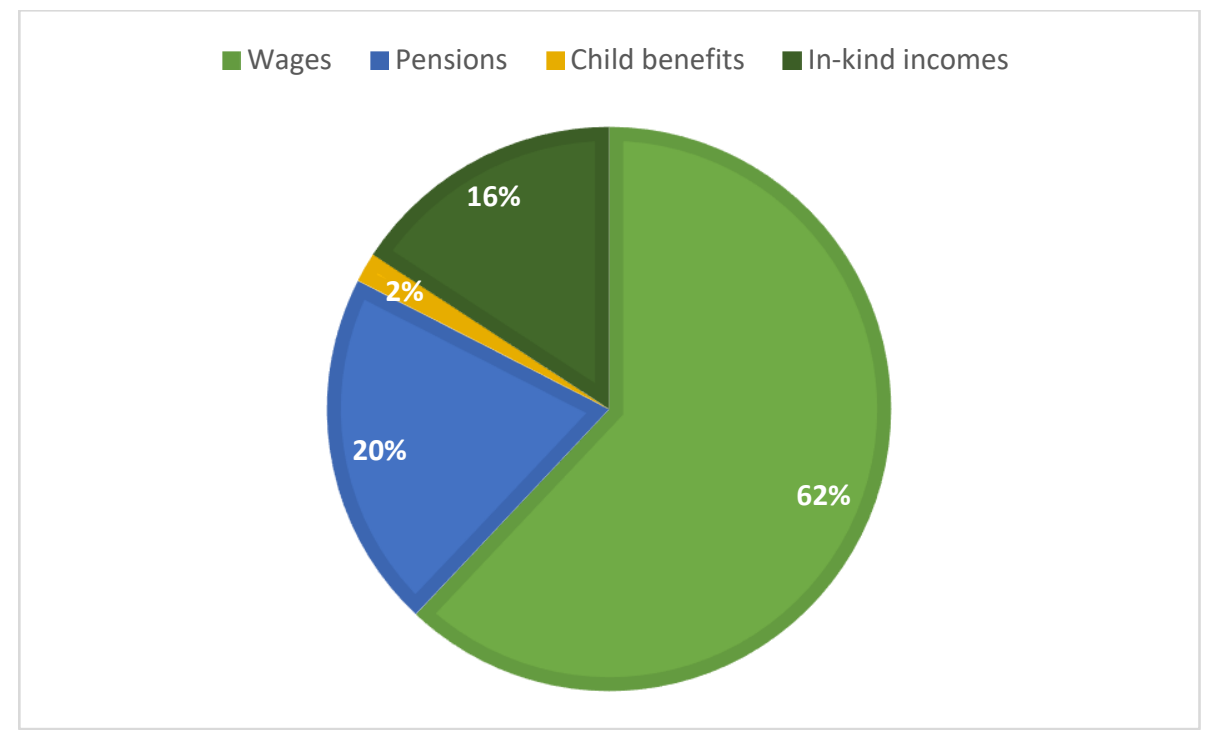

Fig. 2. Structure of Respondents' Total Income, \%

Table 1. Estimated In-Kind Incomes of Rural Households in Yakutia Based on 2017-2019 Sociological Surveys

\begin{tabular}{|c|c|c|c|c|}
\hline No. & Types of incomes from PSP & $\begin{array}{c}\text { Number of } \\
\text { households that } \\
\text { gave affirmative } \\
\text { answers }\end{array}$ & $\begin{array}{l}\text { Average per } \\
1 \text { household }\end{array}$ & $\begin{array}{c}\text { Estimated } \\
\text { mean annual } \\
\text { income per } 1 \\
\text { household, } \\
\text { RUR } \\
\end{array}$ \\
\hline 1 & Greenhouse, vegetable garden & 193 & - & $17,000.0$ \\
\hline 2 & Cattle & 57 & 7.7 heads & $554,594.6$ \\
\hline 3 & Horses & 83 & 7.3 heads & $328,064.5$ \\
\hline 4 & Poultry & 19 & 10 heads & $\mathrm{n} / \mathrm{a}$ \\
\hline 5 & Pigs & 9 & 1.2 heads & $\mathrm{n} / \mathrm{a}$ \\
\hline 6 & Goats & 1 & 1 head & $\mathrm{n} / \mathrm{a}$ \\
\hline 7 & Reindeer & 4 & $\mathrm{n} / \mathrm{a}$ & $\mathrm{n} / \mathrm{a}$ \\
\hline 8 & Land plot within community & 64 & 0.9 ha & \\
\hline 9 & Hayfields & 31 & 3.9 ha & \\
\hline 10 & Pastures & 30 & $11.7 \mathrm{ha}$ & \\
\hline \multirow[t]{2}{*}{11} & Hunting lands (a plot in taiga) & 10 & 507 ha & \\
\hline & Total income from PSP & - & & $217,359.6$ \\
\hline 1 & Hunting & 97 & & $25,927.8$ \\
\hline 2 & Fishing & 102 & & $1,421.6$ \\
\hline \multirow[t]{2}{*}{3} & $\begin{array}{l}\text { Gathering of non-wood forest } \\
\text { resources (berries, mushrooms, } \\
\text { etc.) }\end{array}$ & 254 & & $2,824,8$ \\
\hline & $\begin{array}{l}\text { Total income from traditional } \\
\text { economic activities }\end{array}$ & - & & $8,818.5$ \\
\hline
\end{tabular}


Source: derived by the authors from the study database

Our study has shown that out of 383 surveyed rural households, only 203 or $53 \%$ hold a PSP, of which: 193 have vegetable gardens and greenhouses, and 81 are also engaged in animal husbandry and poultry farming (Table 1.). Such a small proportion of households engaged in PSPs is explained by the fact that rural employment pattern in Yakutia is almost identical to that of urban employment. And this transition had already occurred by the early 2000 s. Currently in agricultural and Arctic districts the share of tertiary employment is about $81-87 \%$, while primary employment accounts for $8-16 \%$, which should be typical for cities, but not for villages. This may indicate both that rural population is highly dependent on public sector employment, and that it has a significant proportion of self-employed [12].

Households engaged in PSPs are usually families with a larger presence of older generations. The average number of retirees in such households is 1.28 versus 1.20 on average, which implies a risk that Yakutia's village residents will be gradually abandoning PSPs in future.

The amount of in-kind incomes from PSPs and traditional resource management across the sample is estimated at RUR 226.2 thousand per year, which accounts for $15.7 \%$ of the total income of the surveyed households (Fig. 2). This is a fairly substantial income item, its size approaching that of retirement pensions, partially compensating for the lack of cash income of the rural population. Mean annual income from a PSP per household amounted to RUR 217.4 thousand per year, which is $93 \%$ of all in-kind incomes or $14.6 \%$ of a total household income. Rural residents also rely on the gifts of local ecosystems: forests, rivers, and lakes. Hunting, fishing, picking berries and other non-wood resources, averaging RUR 8.8 thousand a year, are extremely important for the residents of the region, for they build up food supplies to maintain a traditional diet. Their share in the structure of in-kind incomes is $7 \%$, and that in total income is $1.1 \%$.

\section{Conclusions}

The study undertaken allows for the following conclusions:

- traditional economic activity in form of private subsidiary plots generates about a half of the total agricultural production in the region, providing rural population with employment and food, which partially compensates for the lack of cash income;

- sustainability of subsistence economy is predetermined by poverty of rural population, which places it among priorities for the state and the local authorities of Yakutia;

- the level of in-kind income largely depends on how effective the region's agrarian policy is, primarily in the field of land regulation, as well as on accessibility of forest and water resources. According to a sociological survey, $31.8 \%$ of respondents faces with the problem of access to natural resources. The law 'On private subsidiary plots of citizens in the Sakha Republic (Yakutia)' was adopted 20 years ago, many of its provisions are already outdated. In view of significant changes introduced in recent years, for example, the 'Far Eastern Hectare' program, land relations and other aspects of traditional nature management domain need to be comprehensively analyzed and the legal framework needs to be improved correspondingly;

- purchasing milk from the population is one of the effective measures to support private subsidiary plots. Suitable infrastructure has been put in place in the region: processing units, local production, distribution network. This experience should be tested on other types of agricultural products, as well as non-wood forest resources, and fish. A number of solutions should be envisaged to support local production, primarily investment in advanced 
technologies for processing and storage of products. Development of procurement and processing cooperatives in relatively large rural settlements is the way to solve that problem.

\section{Acknowledgements}

The publication is prepared within framework of the project No. 17-02-00619 'Comparative analysis of the sources of incomes and the problem of poverty in traditional communities of northern regions of Russia, the USA and Canada' supported by funding from the Russian Foundation for Basic Research.

\section{References}

1. S. Sukneva, A. Barashkova, A. Neustroeva, Regional Economics: Theory and Practice, 15-7, 1251-1260 (2017) https://doi.org/10.24891/re .1 5.7.1251.

2. D-L. Popescu, Rural Sustainable Development in Romania, Procedia Economics and Finance, 16, 563 - 567 (2014) https://doi.org/10.1016/S2212-5671(14)00840-5

3. S. Barsykova, V. Radaev, The European electronic newsletter, 13(2), 4-12 (2012) https://publications.hse.ru/en/articles/70677717

4. B.E. Graeub, M. Jahi Chappell., H. Wittman, S. Ledermann, R. Bezner Kerr, B. GemmillHerren, World Development, 87, 1-15 https://doi.org/10.1016/j.worlddev.2015.05.012

5. T. Gavrilyeva, A. Naberezhnaya, M. Ivanova, F. Nikiforov, Living Standards and Quality of Life, 1 (211), 38-47 (2019) DOI: 10.24411/1999-9836-2019-10052

6. G. Dajanova, N. Nikitina, International Research Journal, 12 (78), part 2, (2018) DOI: https://doi.org/10.23670/IRJ.2018.78.12.060

7. N. Guiomar, et al., Land Use Policy, 75, 784-798 (2018) https://doi.org/10.1016/j.landusepol.2018.04.012

8. M. Toader, G.V. Roman, Agriculture and Agricultural Science, Procedia, 6, 89 - 94 (2015) doi: 10.1016/j.aaspro.2015.08.043

9. L. Protopopova, G. Dajanova, Nikonov Readings (All-Russian Institute of Agrarian Problems and Informatics), 21, 188-190, (2016)

10. All-Russian Agricultural Census 2016. Interim Results, Statistical bulletin. Statistika Rossii Information and Publishing Center, (Moscow, 2017) https://www.gks.ru/free_doc/new_site/business/sx/vsxp2016/VSHP-2016.pdf

11. Financing of Milk Procurement in Yakutia Discussed - SakhaLife. https://sakhalife.ru/obsuzhdenyi-voprosyi-finansovogo-obespecheniya-zagotovkimoloka-v-yakutii/

12. T.N. Gavrilyeva, Arktika. XXI century, Humanitarian Sciences, 1 (7), 18-27 (2016) 